\title{
Monsters Escaping the Screen \\ Embodied Narratives of LARPS and Zombie Walks
}

\section{By Kristina STENSTRÖM}

\begin{abstract}
This article engages with communities that invite monstrous characters to come to life and invade three-dimensional spaces through real-life bodies. Through focus group interviews with participants in live action role-play (LARP) and zombie walks in Stockholm, this text explores the ways in which participants engage in physical encounters with monstrosity and the surrounding narrative worlds. First, I address how monstrous corporeality not only functions as fiction or escape but most concretely taps into contemporary discourses connected to corporeal change. Through Butler's performativity and becoming and in connection with discourses of makeover culture, I argue that both LARPs and walks function as both performances and performative acts in which demands connected to idealized corporeal transformation may be concretized, reenacted and renegotiated. Second, the monstrous body here functions simultaneously as an embodied narrative device and a medium. Participants compare the emotional and physical experience of LARPing and zombie walking to that of consuming popular cultural texts in horror or thriller films and television. However, an aspect of zombie walks and LARPs is the concrete physical transformation of those who participate. Furthermore, the use of masks, clothing and jewelry all add tactile dimensions to (or enhance these dimensions in) an embodied experience of a story-world of monsters.
\end{abstract}

\section{KEYWORDS}

Embodied narrative, live-action role-play, zombie walk, becoming, performativity, makeover culture

Kristina Stenström is a postdoctoral researcher at the Department of Media Studies at Stockholm University and part of the research program Existential Terrains: Memory and Meaning in Cultures of Connectivity. Her research interests revolve around transmedia environments, corporeality and the links in-between. 
ZOMBIES, VAMPIRES AND BECOMING IN LATE MODERN MAKEOVER CULTURE

Groping hands, bloody faces and wheezing noises interrupt a Saturday afternoon in central Stockholm as a herd of zombies spill down a busy street. Zombie walks have become increasingly common during the $21^{\text {st }}$ century in cities across the globe. Hundreds or even thousands of individuals, informed by email, social media messages and text messages, gather with strangers to move through the city space dressed and masked as the monsters known from television and cinema (Taylor 2011; Molnár 2014). ${ }^{1}$ Other embodied practices in which monsters are given acting and reacting bodies, such as live action role-play (LARP), have also created narratives and experiences outside of mediated representations during the last decades (Waskul 2006, 20; Bowman 2010, 11).

Representations of zombies and vampires overall have recently become notably prominent through cinema, television and games. Although the vampire has been popular during previous historical periods, and the zombie has previously been prominent in popular culture, depictions have multiplied during the last decade (Flint 2009; Bishop 2009; Höglund 2009; Bailie 2011, 141; Hubner, Leaning and Manning 2015). ${ }^{2}$ According to some scholars (Tenga and Zimmerman 2013), the simultaneous upsurge in popular cultural narratives about vampires and zombies is occurring because these monster types complete each other. While the vampire has been civilized to obey human rules and laws in many contemporary narratives, the zombie has taken over as a truly abject monster. ${ }^{3}$ Monsters of mythology, folklore and popular culture continuously transform and may mirror various issues in different societies at different points in time, but they always embody process and change (Jackson 2003, 122; Cohen 1996).

Narratives about monstrosity or transforming bodies are in no way specific to our time, but I will argue that they are currently tied to contemporary discourses that compel corporeal transformation as beneficial self-representation in what has been called 'makeover culture'. Makeover culture here refers to those discourses that compel individuals to engage a remodeling of the self, not least through the change and development of the body (Jones 2008, 12). In the wake of what Anthony Giddens (2008) has termed 'late modern reflexivity', in which the self becomes a project for each and every one of us to manage, discourses of makeover culture concretize selfreflexive patterns into strategies of change. The upsurge in the sales of self-help books and seminars in recent decades, and the fact that even psychological health is increasingly viewed as an arena of possible self-improvement through therapy and psychotropic medication, exemplifies the same tendencies (Miller 2008; Johansson 2012). Thus, the physical body, its appearance and abilities, is not the only arena of possible improvement in makeover culture, but the body makes transformation manifest and visible, and is therefore a central target for change.

Both vampires and zombies originate in human bodies, but their corporealities are prone to change through decay or the development of monstrous features. Zombies and vampires exemplify the development of early $21^{\text {st }}$ century cinematic and televisual horror, which has moved gradually toward increasingly bloody and explicit depictions of dismembered and destroyed bodies. The monstrous body, rather than the acts of the monster as such, has become the focus of horror narratives (Spooner 2006, 63; Cherry 2009, 122; Ndalianis 2012, 6; Lopez Cruz 2012, 161). The zombie body falls to pieces as it literally rots and breaks down, while the vampire is often depicted as beautiful and sexual. Although their corporealities might seem opposite at first glance, the attributes of zombies and vampires intersect in numerous ways, and their bodies en- 
act numerous prevailing discourses surrounding bodily transformation in makeover culture (Weber 2009; Skeggs and Wood 2008; Heller 2006). I will discuss how zombies and vampires, both as cinematic or televisual representations and through LARPs and zombie walks, can be read as critiques or questioning of makeover culture discourses that compel 'selfregulation' and 'choice' or the very possibility of 'creation of self'.

In several ways, makeover culture discourses crystallize the idea of the self as a volitional creation. Judith Butler has famously critiqued views that sex and gender exist prior to their performative creation through repetition. Performativity, as described by Butler (2006), is separate from performance in the sense that the former is not connected to a volitional subject. While performance is connected to conscious choices, performativity is the replication of cultural codes without conscious choice. Importantly, Butler sees no choosing subject behind the 'doing' of gender and no ' $\mathrm{I}$ ' behind the acts. Butler (1988) argues, for example, that feminist discourse, in its tendency to rely on the category of 'woman', locks the sexed body into a false binary structure of heteronormative possibilities. In contrast, while make-over culture discourses are clearly gendered through a binary structure, they compel individuals to change to reveal an 'inner self' (Weber 2009; Pentney 2012; Heyes 2007, 96); Butler, however, argues that no such self exists.

Historically, certain bodies have been expelled from what is 'acceptable' and deemed monstrous. While depictions of monsters have been read as allegories for certain groups. Butler describes how bodies that have been figuratively or literally punished or expelled are not seen as 'possible' following sexual or racial oppression:

One might wonder what opening up possibilities finally is, but no one who has under- stood what it is to live in the social world as what is 'impossible', illegible, unrealizable, unreal and illegitimate is likely to pose that question. (2006, viii)

The monstrous body is rejected and expelled but also has the potential to question categories related to the body, gender and identity that are perceived as given or natural.

Butler writes that performances, such as drag, can be subversive because they present new ways of viewing existing norms and also question not only what 'is' but also what 'must be':

where the body is not understood as a static and accomplished fact but (...) a mode of becoming that, in becoming otherwise, exceeds the norm, reworks the norm, and makes us see how realities to which we thought we were confined are not written in stone.

(Butler 2004, 29)

Embodied monsters, through practices such as LARPs and walks, can potentially question norms and established ways of being in a similar fashion. This is not to say that practices such as LARPs or zombie walks can be compared to living in oppression or in a forced state of 'monstrosity' as LARPers and walkers can easily remove their costumes and return to a 'non-monstrous' state. Monster narratives may however still reveal contemporary anxieties and fears.

\section{MAKEOVER CULTURE AND FEMALE MONSTROSITY}

Makeover culture discourses insist on change as 'improvement' through individuals' attainment of healthier and more attractive bodies. Media narratives often focus on 'before' and 'after' images to concretize change and improvement (Weber 2009, 12; Johansson 2012, 89). Transformation strategies and arenas of self-im- 
provement are consolidated in the reality television genre of 'makeover television' (Weber 2009; Skeggs and Wood 2008; Heller 2006; Ouellette and Hay 2008). According to Weber (2009), makeover television narratives construct self-transformation as part of a citizenry's responsibility for individual wellbeing. Programs focus on neoliberal values such as individual responsibility and 'choice' and construct corporate philanthropy and volunteer work as sustainable solutions to unjustly distributed societal recourses rather than illustrating their underlying structural causes. Subjects who work hard without substantial support in the form of insurance or health care, and importantly, without complaining, are most worthy of help (Weber 2009, 51; McMurria 2008). While self-governance is rewarded, not following strategies for self-improvement is condemned as irresponsible and immoral; thus, programs construct 'good' and 'bad' citizens (Silk, Francombe and Bachelor 2011). Beverly Skeggs (2009) further notes that makeover shows often construct working class individuals as in need of transformation, thus rejecting certain kinds of people and cultural expressions and making certain individuals and bodies abject. This is in direct opposition to Butler's claim of performative becoming, where no choice exists.

The monstrous bodies of vampires and zombies contrast one another but simultaneously mirror the same aspects of makeover culture through their corporeal beings. Narratives depicting both zombies and vampires contrast 'before' and 'after' states of corporeal transformation, as does makeover culture (Stenström 2015, 124).4 Both monster types further distinctly echo normative corporeal makeovers by either amplifying or opposing the traits of bodily transformation that are prominent in makeover culture. Depictions of both zombies and vampires connect to certain parts of the (female) body also prominent in corporeal narratives in makeover culture.
Both makeover culture discourses, evident through programs, advertisements and the like, and the depictions of vampires and zombies, revolve around skin, teeth and hunger (weight or appetite).

Both monstrous bodies and bodies in makeover transformation can be abject. Abjection is the rejection of that which threatens symbolic order (Kristeva 1982). An obvious abject threat is the opening of corporeal borders, or letting that which belongs inside of the body out. In makeover culture, some forms of abjection can be acceptable: liquid oozing from the body, such as blood, sweat and tears, is seen as evidence of corporeal improvement in progress (Jones 2008, 109-110). Anne Jerslev $(2008,325)$ has linked bodies in horror narratives to bodies undergoing surgery on makeover television. According to Jerslev, both narratives tend to present abject bodies, but the difference is that the makeover genre presents an abjection controlled by the surgeon, where cuts are planned and sutured.

According to Meredith Jones (2008), female celebrities in particular simultaneously exemplify ideal corporeality and failed body projects. Discourses surrounding makeover culture emphasize 'natural' and 'genuine' traits, while excess is deemed inappropriate and a failure. Overtly drastic changes or 'too much' bruising or scarring is considered ridiculous or sad. Women are considered excessive if they become 'too' thin, 'too' suntanned or if surgery or procedures become 'too' obvious, whereas 'successful' transformations do not need explanation or defense. An inability or unwillingness to live up to expected norms, or the failure to code them in a correct manner, can be deemed deviant, threatening, or even monstrous (Heller 2006; Jones 2008; Miller 2008; Weber 2009; Johansson 2012; Pentney 2012). This in turn relates to one of makeover cultures' paradoxes: its construction of bodily alterations as the means of achieving 'authenticity', where original or 
natural bodily traits are changed to reveal an 'inner self' (Weber 2009; Pentney 2012; Heyes 2007, 96).

A central attribute of ideal female beauty in makeover culture is slenderness, which is mirrored in monster narratives. Women are expected to incessantly watch their appetites and work on their bodies to conform to the ideals of a female body (Bordo $2003,202)$. Late modern reflexive makeover culture dictates that female bodies should be slim and fit. Drawing on Helena Mitchie, Susan Bordo (2003, 183) underlines that female hunger has been a representational taboo as it bridges sexual appetite and the appetite for food. Both vampires and zombies have bites and appetites that are dangerous if not kept in check. The vampires' lust and appetite for blood has often been interpreted as a sexual appetite. In many narratives, vampire bites turn the victim into a vampire, which has been interpreted as an allegory for the dangers of (female) sexual awakening (Creed 1993, 66). The vampires' lust can also be understood as symbolic of the forbidden lust for food (Höglund 2000, 123). An out-ofcontrol appetite will leave marks on the surface of the body through weight gain, which women in particular are expected to avoid. In a similar fashion, zombies and vampires are often tainted by what (or whom) they consume as blood - and therefore, forbidden lust - covers their bodies. The zombie body is in a permanent state of monstrosity, and while depictions of vampires shift, vampires eventually give in to their predatory instincts (lust for food).

Makeover culture discourses also centrally target the skin as an aspect of 'self-care'. Female skin in particular should be kept smooth, soft and hair-free and is sunbathed, shaved, epilated, waxed, peeled, made up, cleaned and moisturized (Patterson and Schroeder 2010, 254, 257). Those aspects that Jerslev (2008) described as connecting makeover culture to abjection are all related to the breaking of the skin or the skin as porous and failing to properly separate the inside from the outside. Both zombies and vampires are associated with perforated skin and open bodily boundaries and thus embody the threat of abjection. Zombies in particular often exhibit explicit confusion of the body's surface and its internality as internal tissues or organs may be exposed and the skin might be discolored or damaged. This is an explicit contradiction of makeover culture's ideals of a coherent corporeal unit. Popular cultural depictions of vampires, on the other hand, often show characters with near-perfect and fast-healing skin that corresponds to selfcare strategies in makeover culture, such as those manifested through anti-wrinkle creams. Of course, skin is not connected only to beauty ideals; it has been and continues to be a determinant of access in that only certain kinds of bodies are and have been allowed in certain contexts. Monstrous bodies can be read as the projections of societal fears of certain types of bodies and individuals. Nirmal Puwar, for example, emphasizes that:

Being different from the norm, the bodies of women and non-whites are highly visible (...) the fraternal cathexis of whiteness and masculinity remains invisible, while marked bodies become visible as a psychosomatic invasion' (...). (Puwar 2004, 144-145)

In a similar fashion, Butler (2004) notes that certain lives (or bodies) are not given the same worth if their becoming (their gender) is deemed faulty, and this inequity can truly be a matter of life and death.

\section{EMBODIED NARRATIVES}

Vampires and zombies further connect to material bodies outside of fiction through their ability of literal touch via mediated representations. A growing body of scholarship (Williams 1991; Marks 2002; Sobchack 2004; Barker 2009; Shaviro 
1993; Ndalianis 2012, 39) has focused on visual media experiences that engage audiences by creating physical reactions through what is called 'embodied spectatorship'. Linda Williams (1991) has claimed that this is especially relevant for so-called 'body genres', genres that are thematically close to bodies; such as pornography, weepies and horror, in which 'bodies speak' through orgasms, tears and screams of fear. Visual depictions of bodies and bodily reactions incite physical reactions from audiences. Embodied narratives can and have been further enhanced and deepened through developed media forms. In attempts to engage audiences, an increasing number of transmedia narratives have invited cinema and television audiences to engage in fictive story-worlds, either online or through objects brought out of fictive narratives into the actual reality of potential audiences $^{5}$ (Jenkins 2006; Caldwell 2014). The horror genre in particular has created increasingly immersive experiences by developing storylines through numerous media channels (Ndalianis 2012, 62). In the marketing of The Walking Dead, for instance, both media spaces (such as television, blogs, posters, etc.) and spatial and tactile dimensions were used to blur the lines between diegetic and actual reality. In addition to 'documentary' videos and commercials, the series was advertised by physical zombie characters moving through city spaces and 'attacking' bystanders. LARPs and zombie walks offer a further, very specific monstrous encounter in which participants become both storytellers and audiences. Practices such as these, where the monster is born outside of mediated fiction, invite the transformation of both participants and their surroundings and, importantly, give the monster a concrete, reactive body.

\section{BRINGING MONSTERS OUT TO PLAY}

Much like mediated narratives, both LARPs and zombie walks create fictive narrative worlds of monsters. Both practices invite participants and sometimes bystanders to engage in transformational acts in which costumes and masking are used to bring monstrous characters to life. A LARP is a "role-playing game where participants are required to inhabit their character/role with their physical bodies and where interaction with a material setting defines the game" (Regitzesdatter 2011). LARPs developed from tabletop role-playing games, which started to appear in their modern form during the 1970s and 1980s. Most games since then have belonged to the genres of fantasy, sci-fi and horror (Bowman 2010, 22). In recent decades, roleplaying games have become increasingly mainstream and more widely produced (Waskul 2006, 20; Bowman 2010, 11 ).

The LARP Vampire: The Masquerade in Stockholm is played in a gaming style called 'Nordic LARP', a non-commercial form of role-play that is the most common form in Sweden (Stenros and Montola 2010, 20). Despite its name, Nordic LARP is characterized by its focus on character development and continuous immersive gameplay rather than geography (Waskul 2006, 2021, 34; Stenros 2014, 150-151). In LARPing, the experience itself, and character development in particular, is the main goal. This also applies to zombie walks, where the creation of characters and character interaction are fundamental elements. While LARPs occur in secluded areas or locales, zombie walks make use of city spaces, such a squares and streets. Zombie walks are performed in front of unfamiliar others and thus have a sort of audience that is crucial for the walk to be meaningful. LARPers, on the other hand, function simultaneously as actors and audiences.

For the present study, focus group interviews were conducted to gain access to the worlds of LARPers and zombie walkers. Zombie walkers were approached during a Stockholm zombie walk, and an interview 
with six participants, all still in costume, was completed. As outsiders who are not participating are not allowed access to Vampire: The Masquerade LARPs in Stockholm, interviews could not be conducted within the gaming environment in immediate connection to a LARP. Without immediate contacts in the LARP community, I relied on snowball sampling. A group of five participants was interviewed. 6 Both LARPs and walks are collective practices, and to make use of a pre-existing group dynamic, I wanted group participants to have shared role-playing experiences.

The interviewees, LARPers in particular, noted that a character must have a credible background narrative, which will help the LARPer navigate its creation and presentation. Similarly, the zombie walkers who were interviewed stated that all characters and unfolding events must obey certain rules of logic; for example, the reasons for the zombie outbreak must make sense. This points to a contradictory pattern in both walks and LARPs in which narratives rely on supernatural and 'untrue' premises that do not make ontological sense but are nonetheless expected to be consistent.

"I was a bit irritated by those who did not take their hit, those who would not take a hit... but just continued. I was like, "You are not immortal - you will die from a lead bullet to your skull, I promise you.'” (Zombie walker)

"I would rather believe in a plague than 'rising from the grave' [zombie]... eh... maybe that is actually a possible... future scenario or dystopia or whatever you call it..." (Zombie walker)

“(...) that's like when people talk about Twilight, and I'm like, 'Vampires don't sparkle!' Of course, I do know that vampires do not exist, they are entirely fictional creatures, but having played this game for, like, fifteen years or something... I have... a picture of how vampires are... and that vision is based on this rule system." (Vampire LARPer)

The interviewed LARPers and walkers evaluated their respective practices in relation to their ability to create corporeal responses and engagement, and they compared those sentiments to those that mediated horror fiction awakens. For example, the gaming environment in Vampire: The Masquerade is described as tinged by an atmosphere of anticipation reminiscent of that evoked by mediated horror fiction. LARPers describe World of Darkness, the in-game universe where the game unfolds, as reminiscent of our world and mainly built on structures and intuitions that define our societies outside of fiction. However, World of Darkness, as its name suggests, is a darker, more corrupt and more sinister place, much as its monstrous inhabitants embody more darkness than an average human would admit to.

During both LARPs and walks, the monster character is born, in a sense, through clothing, masks, jewelry and the like. The interviewees agreed that concrete physical preparations are necessary to make the inner experience of game immersion possible. Zombie walks and Nordic LARPs, in contrast to several other forms of LARP, encourage all possible actions and events to be acted out physically. Nordic LARPs in particular also avoid symbolic props and strive to make and use props that are as authentic as possible. A weapon used in a LARP, for instance, should look like a weapon rather than a toy. The LARPers and walkers explained that certain tactile objects become tinged with associations with the game world and can thus bridge the everyday world and the fictional narrative. The interviewees also described a further sense of becoming that is even more deeply corporeally connected to the zombie walker or LARPer her/himself. By changing their patterns of movement and voices or by listening to certain music, both 
LARPers and walkers inhabit their roles and achieve an emotional and physical immersion in the game or walk (Stenros $2014,150)$. The body's emotional responses to certain movements or voices are invaluable to LARPer or walker's performance of his/her role. In other forms of LARP, physical contact between LARPers might be forbidden, and actions may be shown on cards rather than played out. LARPers use physical activities as part of their LARPing to demonstrate these actions. This was described by one of the participants as follows:

“Everyone has their own little idea, but it's usually something that you do with your body, you fiddle with something or... walking is very common (...) You either walk around or you go get something, you have a little ritual (...) You can call it an autonomous tactile activity $(. .$.$) " (Vampire LARPer)$

LARPers thus use the body both as an instrument to perform the role and as a means of gaining access to and becoming the character. The interviewed participants described the narrative as taking place in them rather than around them. The participant's bodies and corporeal reactions are part of the gaming experience for themselves and for the other participants. An important part of the game is identifying with one's character. The body becomes a medium through which the narrative unfolds, and as one's own body is used to stage anger, fear, etc., the emotions of anger or fear follow. The interviewees described feeling their character's fear, a phenomenon that is known as 'bleed' in LARPing environments. While 'immersion' partly refers the collective gaming experience, 'bleed' pertains to the experience of an individual player (White et al. 2012, 71$72,82)$. Here, the player's engagement in a particular character or his or her reality and conditions either 'bleed out' into the gamer's reality outside of the game, or the reality of the player 'bleeds in' to the game. The interviewed LARPers explained that characters can react differently than the role-players themselves would in a given situation. The characters in the game can be used to experience fear and anticipation from a safe distance; the experience is immersive enough to awake intense feelings of fear, sympathy or excitement, but at all times, LARPers are aware at some level that they are participating in a fictional game where the consequences only last as long as the LARP does. Importantly, though, the LARP is not entirely contained within a fictional world. The interviewed participants described how the LARP itself and its characters merge with their everyday lives, where they use their experiences from LARPing, and vice versa.

"I like to explore my character... I like to think what another person would think in these... circumstances... that I hope that I would never get into." (Vampire LARPer)

"I once had to replace an administrator for two weeks and I had no idea about this work... but the one who hired me, she was playing LARP with me, and she said: 'You just imagine that you are playing the character!' And it was a lot of fun. I would dress up in the morning as I imagined an administrator should dress up... and smiled the whole day." (Vampire LARPer)

\section{WEARING MONSTROSITY}

LARPs in particular, but also walks to a certain degree, depend upon the construction of a character that is developed and improved during the event. Nordic LARP is characterized by strong game immersion in the distinction between character, LARPer and individual (him or herself) is porous. The character is a fictional construct that comes to life through the LARPer, who is also in some respects distinct from who he or she is outside of LARPing (individual). 
Timm Knudsen $(2005,270)$ views LARPs as performative arenas of identity; here, the term 'performative' refers to how the subject continues to create him- or herself and how identity is the result of actions in the game world rather than a driving force behind the actions themselves. LARPers are physically engaged in the games: they are aware of their participation but still invest in the game and the experience of being 'someone else'. Adopting a role in a game or a walk allows participants to test personality traits or entire sets of selfhood that either consolidate existing traits or oppose them. Furthermore, expectations regarding physical appearance and corporeal change that permeate participants' relationship to their own bodies on an implicit level must enter these conscious layers of play. I argue that this resembles the performative dimensions of everyday life, in which gender, according to Butler (2006), is constantly performatively constructed and maintained. The focus group participants who engaged in the game said they are initially aware of the role they are performing and the way they move, talk and act. However, they described a shift that occurs during the game as their performance becomes increasingly automatized:

“(...) when you have a character, you always explore new things... that's one of the wonderful things about LARP, that you can explore things that you cannot in real life." (Vampire LARPer)

"Of course, you can LARP something and play pretend about something that is not real... of course. It's about living up to fantasies or a dream, or a vision of the future or... I have a character that I've created, according to my own storyline.” (Zombie walker)

If we view actions as becoming, in a Butlerian sense, LARPers and walkers describe their monstrous transformation as starting in their physical being and the emotional response being just that: a response to actions performed on a sort of stage. Butler uses terminology from theatrical discourse, such as 'act', to indicate a performance or acting on a stage. However, she emphasizes that it is misleading to claim that acts that create gender performances would be created or chosen by any particular volatile subject or group (Butler 1988, 526). The acts of bodily transformation connected to the role of a monstrous character are connected to both conscious and performative acts. The monstrous body simultaneously offers dimensions of becoming through both concrete acts and through the theme of 'impossible bodies'; thus, it might create an opening for corporeal dimensions that the LARPer or walker might not be fully aware of. If LARPs and walks function as both performances and performative acts, demands connected to bodily change can be concretized and reenacted in a form other than the idealized one. The monstrous body per se, and the monster embodied through performative practices in particular, are opportunities to defy categories and open up possible ways of being, acting and creating self. LARPs and walks offer roles and modes of being that either oppose or negotiate those outside the narrative world.

For instance, male LARPers or walkers may enact female characters and vice versa in what is called 'crossgender role-play' (Vorobyeva 2015; Osborne 2012). Of course, it is unrealistic to expect role-play participants to be entirely freed from the discourses and norms of their everyday lives when they enter LARPs or walks. On the contrary, Vorobyeva (2015) describes how stereotypes and gendered expectations are brought in to the LARP world, for instance, through suspicions that females are too sensitive to play male roles properly. Further, it is overly optimistic to expect that role-play in theory could be open to any interpretation of gender, sexuality and so forth and that participants will be entire- 
ly freed from the binary construct or 'the heterosexual matrix' (Butler 1988) that dominates off-game life.

Both zombies and vampires can be read as reactions to makeover culture because they embody a revelation of the threats and risks involved in bodily transformations. The zombie is almost always part of a herd and is most dangerous when surrounded by other zombies; it is part of a collective defined by its surroundings as it has lost all consciousness and ability to choose. Therefore, the zombie (herd) can easily be read as an allegory for the uncritical mass or consumerism (Horne 1992, 97; Warner $2006,357)$. The monstrous transformation of the zombie body is one of very manifest breakdown and loss as it rots and its body breaks down; in comparison, in late modernity, bodies are 'built' and constructed through improvement strategies. Thus, the zombie in simultaneously embodies the ultimate failure of makeover culture strategies and the loss of (or liberation from) reflexivity. For audiences, LARPers and walkers, dual embodiment functions as both a threat and a reminder of possible failure and as a reminder of possible liberation from straining discourses and expectations. On the other hand, vampires in similar productions present a polished and beautiful façade while harboring monstrous features and dangerous habits that cannot be seen at first glance. The vampire reminds audiences of the paradoxes and risks inherent to makeover culture, as strategies of self-improvement come with contradictory or unexpected effects. The vampire transforms into an (in many respects) ideal body; in doing so, it loses its authenticity (humanity). The vampire is most often attractive, it cannot be hurt physically (or is injured only with great difficulty) and it does not age. The vampire attains everlasting youth but does not gain access to an 'inner self' through transformation; on the contrary, it loses its original sense of selfhood. It can no longer fully connect to human emotions and is taken over by a lust for blood that can often overshadow any human instinct or sentiment; thus, the vampire is no longer an authentic human, although it looks like an ideal one. Overall, the monstrous 'makeover' illustrates a previous life left behind, much as the discourses on the self-reflexive makeover project promise 'death' to a previous life and body but at a high price.

The theme of transformation of the monstrous body is a reaction and, in certain respects, a protest against those discourses that demand bodily change in accordance with certain norms and ideals in late modern makeover culture. While makeover culture dictates or demands change and development in a strict and precise way for that change to be valued as successful, narratives of monstrosity show bodies in decay or in danger. The monstrous transformation furthermore shows a body without and out of control; that is, the monstrous character can neither control itself nor be controlled from the outside, whereas the late modern makeover culture is about purposeful and controlled change. Embodied narratives of selfhood through bodily discipline and optimization have become increasingly manifest. The monster, however, illustrates both risks and possibilities; change either comes with a price or means the breakdown of bodily order altogether.

\section{NOTES}

1. The first non-commercial zombie walk was arranged in Toronto in 2003 (Cocarla 2011, 114). 2 . A vampire series that quickly gained cult status is Buffy the Vampire Slayer (1997-2003), which was followed by a spin-off, Angel (2000-2004). Other series are Blade: The Series (2006), Moonlight (2007-2008), Being Human (BBC, 20092013), The Vampire Diaries (2009-now) and Being Human (SyFy, 2011-2014). During the last decade, vampires have been increasingly visible in 
cinematic productions such as Twilight (20082012), a series of five movies, and in Underworld (2003), Underworld Awakening (2012), Låt den rätta komma in (2008), Let me in (2010), Only Lovers Left Alive (2014) and Dracula Untold (2014). Televised programs in the zombie genre include Bite $\mathrm{Me}$ (2010-2012), The Walking Dead (2010-), Project Phoenix (2012), Dead Set (2008), In the Flesh (2013-now) and iZombie (2015).

Movies such as Resident Evil (2002), 28 Days Later (2002), 28 Weeks Later (2007), I Am Legend (2007) and World War Z (2013) have also depicted zombies. The zombie has been presented as a comical character in productions such as Shaun of the Dead (2004), Fido (2006), Dead Snow (2009), Zombieland (2009) and Warm Bodies (2013).

3 . Corporeal transformation is certainly not a new horror theme; however, narratives about transformation have developed by placing the transforming character closer to the audience's everyday environments. Zombie outbreaks and vampires disrupt cities, neighborhoods, and schools that resemble those known to the audience.

4. Particular examples are the television series True Blood (2008-2014) and The Walking Dead (2010now), which are just two examples within wide array of televisual and cinematic depictions.

5 . For example, toys, clothing or jewelry, referred to as 'tactile transmedia' by Gilligan (2012).

6. Browne (2005) argues that snowball sampling is a particularly fruitful strategy in the search for informants and respondents in relation to sensitive topics. This study, on the other hand, required initiated, 'native' contacts who were familiar with the LARP context. In both cases, contacts are more likely to participate if asked by someone who is already familiar to them. I contacted a LARPer on Facebook through a common acquaintance. I asked the LARPer to contact people who may be interested in participating in a study, and she chose to create a group on Facebook where she invited possible participants.

\section{REFERENCES}

- Bailie, H. 2011. Blood Ties: The Vampire Lover in the Popular Romance. The Journal of American Culture. 34(2), 141-148.

- Barker, J. M. 2009. The Tactile Eye: Touch and the Cinematic Experience. Berkeley: University of California Press.

- Bishop, K. 2009. Dead Man Still Walking: Ex- plaining the Zombie Renaissance. Journal of Popular Film and Television. 37(1), 16-25.

- Bordo, S. 2003. Unbearable Weight: Feminism, Western Culture, and the Body. $10^{\text {th }}$ edition.

Berkeley: University of California Press.

- Bowman, S. L. 2010. The Functions of Role-Playing Games: How Participants Create Community, Solve Problems and Explore Identity. Jefferson: McFarland \& Company, Inc., Publishers.

- Browne, K. 2005. Snowball Sampling: Using Social Networks to Research Non-heterosexual Women. International Journal of Social Research Methodology. 8(1), 47-60.

- Butler, J. 1988. Performative Acts and Gender Constitution: An Essay in Phenomenology and Feminist Theory. Theatre Journal. 40(4), 519-531. - Butler, J. 2006. Gender Trouble: Feminism and the Subversion of Identity. London/New York: Routledge.

- Butler, J. 2004. Undoing Gender. New York: Routledge.

- Caldwell, J. T., 2014. Post-Network Reflexivity: Viral Marketing and Labor Management. In: Mann, D. ed. Wired TV: Laboring Over an Interactive Future. New Brunswick: Rutgers University Press, 140-160.

- Cherry, B. 2009. Horror. London: Routledge.

- Cocarla, S. 2011. Reclaiming Public Spaces Through Performance of the Zombie Walk. In: Smith, R. ed. Braaaiiinnnsss: From Academics to Zombies. Ottawa: University of Ottawa Press, 113131.

- Cohen, J. J. 1996. Monster Culture (Seven Theses). In: Cohen, J. J. ed. Monster theory: Reading Culture. Minneapolis: University of Minnesota Press, 3-25.

. Creed, B. 1993. The Monstrous-Feminine: Film, Feminism and Psychoanalysis. London: Routledge. - Flint, D. 2009. Zombie Holocaust: How the Living Dead Devoured Pop Culture. London: Plexus.

- Giddens, A. 2008. Modernitet och självidentitet: självet och sambället $i$ den senmoderna epoken. Göteborg: Daidalos.

- Gilligan, S. 2012. Heaving Cleavages and Fantastic Frock Coats: Gender Fluidity, Celebrity and Tactile Transmediality in Contemporary Costume Cinema. Film, Fashion es Consumption. 1(1), 7-38. - Heller, D. 2006. The Great American Makeover: Television, History, Nation. New York: Palgrave Macmillan.

- Heyes, C. 2007. Self-Transformations: Foucault, Ethics, and Normalized Bodies. New York: Oxford University Press.

- Horne, P. 1992. I Shopped With a Zombie. Critical Quarterly. 34(4), 97-110. 
· Hubner, L., Leaning, M and Manning, P. 2015. The Zombie Renaissance in Popular Culture. London: Palgrave Macmillan.

- Höglund, A. 2000. Vampyrens hunger. In: Jonsson, K. and Öhman, A. eds. Populära fiktioner. Stockholm: Brutus Östlings Bokförlag Symposion.

. Höglund, A. 2009. Vampyrer: En kulturkritisk studie av den västerländska vampyrberättelsen från 1700-talet till 2000-talet. Växjö: Växjö University Press.

- Jackson, R. 2003. Fantasy: The Literature of Subversion. London/New York: Routledge.

- Jenkins, H. 2006. Convergence Culture: Where

Old and New Media Collide. New York: New York University Press.

- Jerslev, A. 2008. Cosmetic Surgery and Mediated Body Theatre: The Designable Body in the Makeover Programme The Swan. New Review of Film and Television Studies. 6(3), 323-341.

- Johansson, T. 2012. Kändisfabriken: Identitet, makeover och kroppens tid. Stockholm: Carlssons Bokförlag.

- Jones, M. 2008. Skintight: An Anatomy of Cosmetic Surgery. Oxford/New York: Berg Publishers. - Kristeva, J. 1982. Powers of Horror - An Essay on Abjection. New York: Columbia University Press. - Lopez Cruz, R. A. 2012. Mutations and Metamorphoses: Body Horror is Biological Horror. Journal of Popular Film and Television. 40(4), 160-168.

- Marks, L. 2002. Touch: Sensuous Theory And Multisensory Media. Minneapolis: University of Minnesota Press.

- McMurria, J. 2008. Desperate Citizens and Good Samaritans: Neoliberalism and Makeover Reality TV. Television \& New Media. 9(4), 305332 .

- Miller, T. 2008. Makeover Nation: The United States of Reinvention. Columbus: The Ohio State University Press.

- Molnár, V. 2014 Reframing Public Space Through Digital Mobilization: Flash Mobs and Contemporary Urban Youth Culture. Space and Culture. 17(1), 43-58.

- Ndalianis, A. 2012. The Horror Sensorium: Media and the Senses. Jefferson: McFarland \& Company, Inc., Publishers.

- Osborne, H. 2012. Performing Self, Performing Character: Exploring Gender Performativity in Online Role-Playing Games. Transformative Works and Cultures. 11

- Ouellette, L. and Hay, J. 2008. Better Living Through Reality TV. Television and Post-welfare Citizenship. Malden: Blackwell Publishing.
- Patterson, M. and Schroeder, J. 2010. Borderlines: Skin, Tattoos and Consumer Culture Theory. Marketing Theory. 10(3), 253-267.

- Pentney, B. A. 2012. Shaping Embodiment in The Swan: Fan and Blog Discourses in Makeover Culture. Burnaby: Simon Fraser University.

- Puwar, N. 2004. Space Invaders: Race, Gender and Bodies Out of Place. Oxford/New York: Berg.

- Regitzesdatter, J. 2011. Doing Gender at Larp. In: Duus Henriksen, T. et al. eds. Think Larp: Academic Writings from KP2011. Copenhagen: Rollespilsakademiet, 70-85.

- Shaviro, S. 1993. The Cinematic Body. Minneapolis: University of Minnesota Press.

. Silk, M. L., Francombe, J. and Bachelor, F. 2011. The Biggest Loser: The Discursive Constitution of Fatness. Interactions: Studies in Communication and Culture. 1(3), 369-389.

- Skeggs, B. 2009. The Moral Economy of Person Production: The Class Relations of Self-Performance on "Reality" Television. The Sociological Review. 57(4), 626-644

- Skeggs, B. and Wood, H. 2008. The Labour of Transformation and Circuits of Value "Around" Reality Television. Continuum: Journal of Media o Cultural Studies. 22(4), 559-572.

- Sobchack, V. 2004. Carnal Thoughts: Embodiment and Moving Image Culture. Berkeley: University of California Press.

Spooner, C. 2006. Contemporary Gothic. London: Reaktion Books.

-Stenros, J. and Montola, M. 2010. The Paradox of Nordic Larp Culture. In: Stenros, J. and Montola, M. eds. Nordic Larp. Stockholm: Fëa Livia, 15-29.

. Stenros, J. 2014. What Does "Nordic Larp" Mean?. In: Back, J. ed. The Cutting Edge of Nordic Larp. Denmark: Knutpunkt, 147-155.

- Stenström, K. 2015. Monsterkroppar: transformation, transmedialitet och makeoverkultur.

Stockholm: Stockholm University.

- Taylor, J. M. 2011. 21 ${ }^{\text {st }}$ Century Zombies: New Media, Cinema and Performance. Berkeley: University of California

- Tenga, A. and Zimmerman, E. 2013. Vampire Gentlemen and Zombie Beasts. Gothic Studies. 15(1), 76-87.

- Timm Knudsen, B. 2005. It's live. Performativity and Role-playing. In: Gade, R. and Jerslev, A. eds. Performative Realism: Interdisciplinary Studies in Art and Media. Copenhagen: Museum Tusculanum Press, 269-290.

- Vorobyeva, O. 2015. Crossgender Role-playing in Russian Larps. In: Bowman, S. L. ed. Wyrd Con 
Companion Book 2015. Costa Mesa: Wyrd Con, 60-69.

- Warner, M. 2006. Phantasmagoria: Spirit Visions, Metaphors, and Media into the Twenty-first Century. Oxford: Oxford University Press.

-Waskul, D. 2006. The Role-Playing Game and the Game of Role-Playing: The Ludic Self and Everyday Life. In: Williams, J. P, Hendricks, S. Q. and Winkler, K. eds. Gaming as Culture: Essays on
Reality, Identity and Experience in Fantasy Games. London: McFarland \& Company, Inc., Publishers, 19-38.

. Williams, L. 1991. Film Bodies: Gender, Genre, and Excess. Film Quarterly. 44(4), 2-13.

- Weber, B. R. 2009. Makeover TV: Selfhood, Citizenship, and Celebrity. Durham/London: Duke University Press.

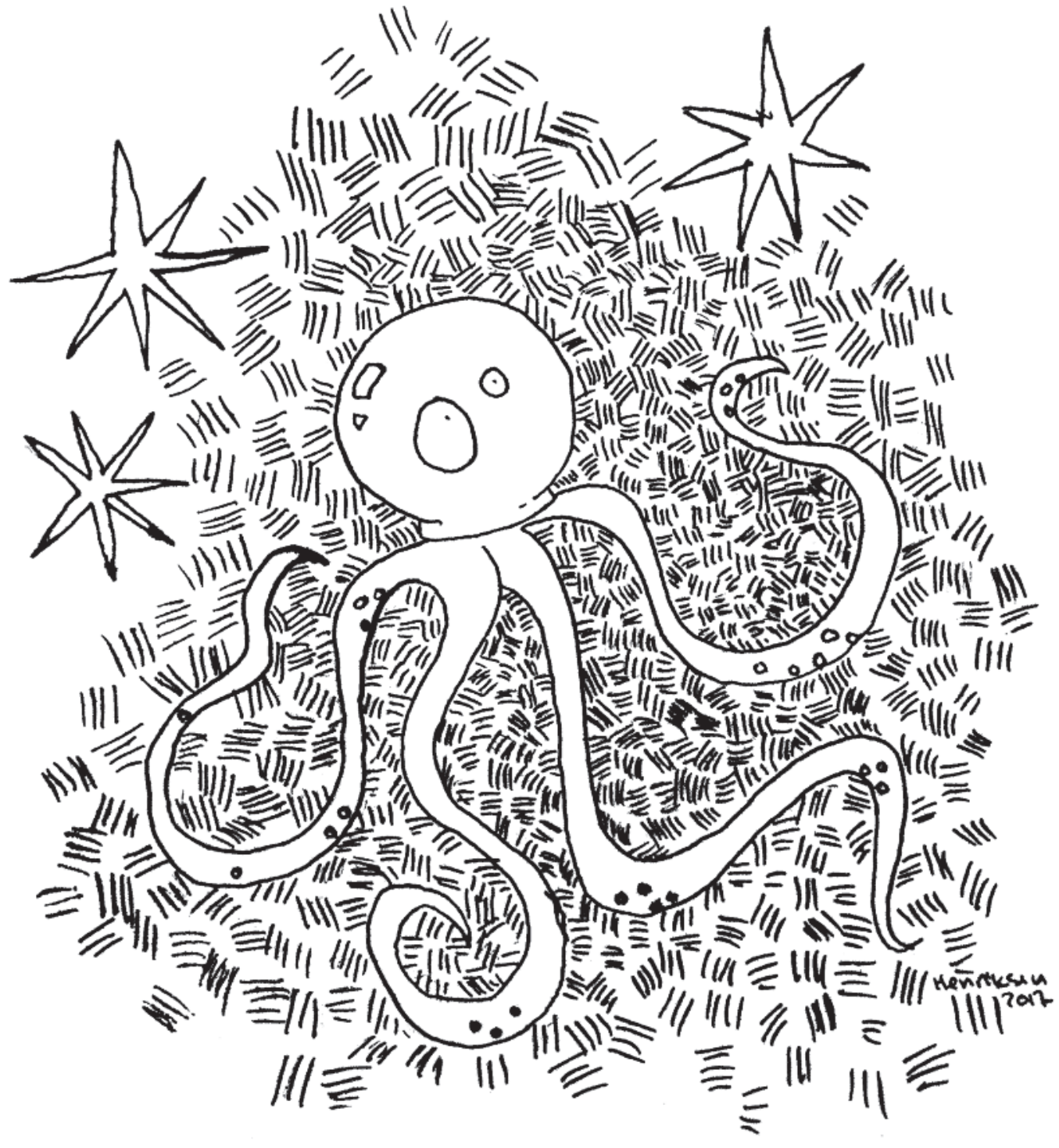

